\title{
A multi-level strategy for anticipating future glacier lake formation and associated hazard potentials
}

\author{
H. Frey, W. Haeberli, A. Linsbauer, C. Huggel, and F. Paul \\ Department of Geography, Universtity of Zurich, Switzerland
}

Received: 30 October 2009 - Revised: 10 February 2010 - Accepted: 12 February 2010 - Published: 22 February 2010

\begin{abstract}
In the course of glacier retreat, new glacier lakes can develop. As such lakes can be a source of natural hazards, strategies for predicting future glacier lake formation are important for an early planning of safety measures. In this article, a multi-level strategy for the identification of overdeepened parts of the glacier beds and, hence, sites with potential future lake formation, is presented. At the first two of the four levels of this strategy, glacier bed overdeepenings are estimated qualitatively and over large regions based on a digital elevation model (DEM) and digital glacier outlines. On level 3, more detailed and laborious models are applied for modeling the glacier bed topography over smaller regions; and on level 4, special situations must be investigated in-situ with detailed measurements such as geophysical soundings. The approaches of the strategy are validated using historical data from Trift Glacier, where a lake formed over the past decade. Scenarios of future glacier lakes are shown for the two test regions Aletsch and Bernina in the Swiss Alps. In the Bernina region, potential future lake outbursts are modeled, using a GIS-based hydrological flow routing model. As shown by a corresponding test, the ASTER GDEM and the SRTM DEM are both suitable to be used within the proposed strategy. Application of this strategy in other mountain regions of the world is therefore possible as well.
\end{abstract}

\section{Introduction}

In proximity to melting conditions, snow and ice react sensitively to climate change (Haeberli and Beniston, 1998). As a consequence, high-mountain landscapes that are dominated by glacial and periglacial processes are influenced by the

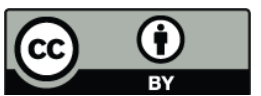

Correspondence to: H. Frey

(holger.frey@geo.uzh.ch) governing climatic conditions and their changes. The continuous rapid retreat of glaciers in mountain ranges all over the world is one of the most obvious and reliable indicators of global warming (GCOS, 2004; Lemke et al., 2007); it is well visible and easily understandable for a wider public. Glaciers are also symbols of an intact environment, thus glacier retreat also has a strong impact on the perception of the landscape (WGMS, 2008; Haeberli, 2005).

Fast changes of the high-mountain cryosphere affect various phenomena, processes and process interactions and can lead to hazard situations beyond historically known conditions. Associated with glacier retreat, pro-glacial lakes can form behind moraine dams or in overdeepened parts of the exposed glacier bed. Such new lakes are attractive elements in a landscape and compensate to a certain degree the loss of attractiveness from glacier disappearance (Haeberli and Hohmann, 2008). They also constitute interesting potentials for hydropower production. However, glacier lakes can pose a potential threat to the population and infrastructure in the valleys below as they are forming in an environment dominated by interacting, rapidly changing and highly dynamic processes.

The most severe glacier catastrophes often result from a combination and chain reaction of different processes (Huggel et al., 2004; Kääb et al., 2005; Reynolds GeoScience Ltd, 2003). In glaciated environments, the following changes affect the hazard situation of glacier lakes:

- Glacier retreat can lead to the development of new potential ice avalanche starting zones (Clague and Evans, 2000; Kääb et al., 2005; Richardson and Reynolds, 2000a; Kershaw et al., 2005).

- Transitions in the thermal regime of hanging glaciers, from cold to polythermal or temperate, can destabilize them due to reduced basal friction (Alean, 1985; Fischer et al., 2006; Huggel, 2009). 
- The retreat and thinning of glaciers since the Little Ice Age has a destabilizing effect on steep adjacent rockwalls due to the related debuttressing effect (Augustinus, 1995; Ballantyne, 2002). Such rock walls can be situated close to newly forming glacier lakes (e.g. the Schlossplatten rock fall and -toppling at the tongue of the Lower Grindelwald Glacier) (Oppikofer et al., 2008).

- Glacier retreat often exposes morainic and unconsolidated material (Evans and Clague, 1994) that, if situated in steep terrain, is prone to be the starting zone for landslides and debris flows (Huggel et al., 2004; Haeberli et al., 1991; Hubbard et al., 2005).

- The formation of new glacier lakes itself is a potential threat because an outburst of such a new lake can initiate a cascade-like chain reaction involving other lakes located further downstream (cf. Gruben Glacier, Haeberli et al., 2001).

- Regions with warm permafrost conditions are expected to show the most critical stability conditions of frozen rock walls (e.g., Gruber and Haeberli, 2007). With increasing air temperatures, permafrost degradation and thus deep long-term warming of such rock walls will increase the probability of rock falls. Glacier lake outbursts triggered by rock fall will thus be a scenario of increasing probability in the future.

- Permafrost degradation also reduces the stability of moraine dams that contain dead ice or other subsurface ice (Richardson and Reynolds, 2000b).

Detecting and monitoring of existing glacier lakes by remote sensing methods (Allen et al., 2009; Frey et al., 2010; Huggel et al., 2002; Kääb et al., 2005) as well as field investigations with geophysical methods (Haeberli et al., 2001; Richardson and Reynolds, 2000a) are a research focus in various mountain regions.

Knowledge about sites with potential future lake formation would thus be a useful basis for decision-making by the responsible authorities. So far, only little research has been done in the field of detecting sites with potential future lake formation. Reynolds (2000) found a slope gradient of $2^{\circ}$ to be the critical threshold for supraglacial lake formation on debris-covered glaciers in the Himalayas. Quincey et al. (2007) confirmed this finding and concluded that debriscovered glacier parts with low flow velocities are most likely sites with a potential for supraglacial lake formation.

In this study, we present a multi-level strategy to anticipate the formation of future glacier lakes at different scale levels. At all levels, local overdeepenings in the glacier bed are estimated by analyzing the current glacier surface characteristics based on digital elevation models (DEMs), digital glacier outlines and satellite imagery. Such input information is widely available, enabling the methods to be applied to other mountain ranges in the world. The focus of this study is on the quick and qualitative assessment of potential future lake formation in regions, where only sparse data are available. Therefore, the first two larger-scale levels of the strategy are the main focus of this paper; the third and the fourth level relate to existing, but more laborious approaches and are not discussed in detail.

The paper first describes the test sites and the used data before the methods of the four strategy-levels for future lake detection and hazard assessment are presented. In view of the obvious difficulty of verifying predictions of future conditions, the approaches are validated using historic data at a test site in the Bernese Alps (Trift Glacier), where a proglacial lake formed recently. Scenarios of future lake formation are then derived for the two regions Bernina and Aletsch. In addition, the likely runout path of a flood from potential outbursts of expected future lakes are modeled in the Bernina region. In view of applying the approach to other regions in the world, the influence of different DEMs on the results is tested as well.

\section{Test sites and data}

\subsection{Test sites}

Although the presented approach is intended to be globally applicable, we chose test sites in the Swiss Alps for this study due to the good data availability, including a high-quality DEM and various historical maps since the middle of the 19th century. The methods for the detection of overdeepenings in the glacier bed are verified at Trift Glacier in the Bernese Alps (Fig. 1). Since the mid 1980's, the tongue of this glacier experienced strong down-wasting (Paul and Haeberli, 2008) and finally collapsed between 2000 and 2005. A new lake (length $1 \mathrm{~km}$, max. width $450 \mathrm{~m}$ ) formed, which contributed to the rapid disintegration of the glacier tongue. The location is easily accessible and a suspension bridge over the gorge at the end of the lake attracts many tourists in summertime. We applied the assessment strategy on data from before the start of the lake formation (i.e., before 2000), to analyze whether the formation of this lake could have been anticipated with this approach.

For the Aletsch and Bernina regions (Fig. 1), scenarios of potential future lakes are presented. The testing of the different DEMs and the preliminary hazard assessment are performed in the Bernina region. In both regions, glaciers are prominent elements of the landscape (the Aletsch Glacier is the largest glacier of the Alps and part of the UNESCO world heritage Swiss Alps Jungfrau-Aletsch) and of high economic importance for tourism.

\subsection{Input data}

The used DEM was produced by the Swiss Federal Office of Topography (swisstopo) and has a cell size of $25 \mathrm{~m}$. This 


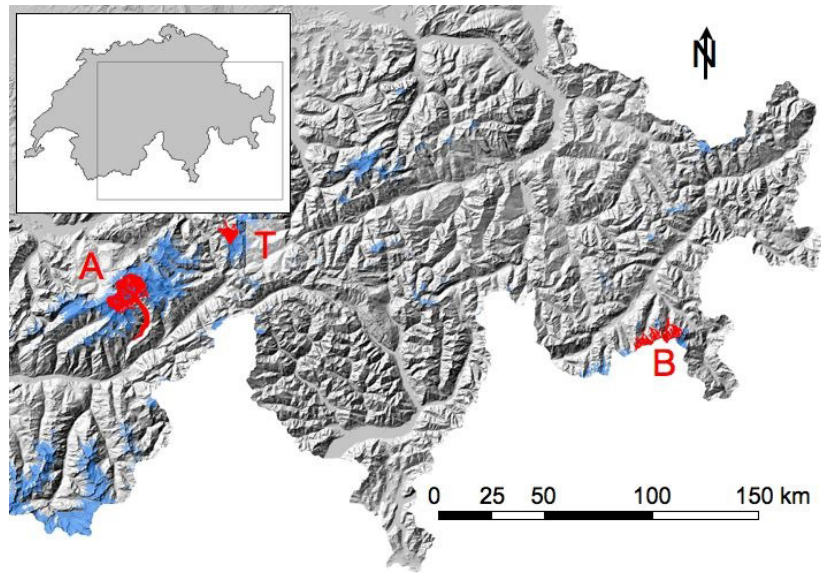

Fig. 1. Overview of the study regions. Aletsch Glacier (A), Trift Glacier (T) and the Bernina region (B) are shown in red, other glaciers are shown in light blue. The relief is depicted as a hillshade view of the DHM25L2.

dataset is based on the interpolation of contour lines from the Swiss National Map (1:25000) and includes digitized lake perimeters, main break lines and spot heights. Two editions of this data set are available: a Level 1 (DHM25L1) and a Level 2 (DHM25L2) version, which primarily vary regarding the algorithms for the contour line interpolation and the acquisition date (Swisstopo, 2004). The DHM25L1 was acquired around 1985, whereas in the DHM25L2 the contour lines of glaciers were updated to the state of around 1995, except for the Bernina region. In view of applying the here presented approaches to other regions in the world, the influence of the DEM quality on the result is tested in the Bernina region for different DEMs, including the global DEM compiled from ASTER data (ASTER GDEM, Hayakawa et al., 2008) and the DEM from the Shuttle Radar Topography Mission (SRTM, Farr et al., 2007) in addition to the DHM25L2.

To determine the glacier extent, we used glacier outlines from the Swiss Glacier Inventory (SGI, described in Paul, 2007). Regarding applications to other regions, digital glacier outlines can be found for example in the Global Land Ice Measurement from Space (GLIMS) glacier database (Raup et al., 2007). To study the crevasse pattern of glaciers, the panchromatic channel with a resampled spatial resolution of $10 \mathrm{~m}$ from two scenes of the Indian Remote Sensing satellite (IRS-1C) from September 1997 were used.

For the validation at Trift Glacier, the corresponding map sheet of the Siegfriedkarte is used, a precursor of the actual topographic map of Switzerland. For the Alps, the Siegfriedmap has a 1:50000 scale and we used the 1932 edition of sheet number 392 "Meiringen".

\section{Methods}

\subsection{Strategy to detect glacier bed overdeepenings}

Glaciers have a considerable erosive power, which - unlike fluvial erosion - can result in large depressions in the bed. When such overdeepened parts of the glacier bed are exposed after glacier disappearance and filled with (melt-) water rather than with sediments, new proglacial lakes appear (Clague and Evans, 1994; Costa and Schuster, 1988). In other words, sites with potential future lake formation can be identified by detecting overdeepenings in the glacier bed. Roughness and irregularities of the glacier bed induce stresses to the glacier ice, which are compensated to a certain degree by deformation. But due to the non-perfect plasticity of ice, bed irregularities are only partly compensated. Hence, the glacier surface topography is in principle a smoothed image of the underlying bed, and the current glacier surface can serve as a key to identify overdeepened parts of the glacier bed (Oerlemanns, 2001).

A multi-scale approach for identifying such overdeepenings allows to cover large regions on the one hand (level 1 and level 2), and to analyze selected situations in more detail (level 3 and level 4) on the other hand.

The assessment strategy integrates the following four levels (Fig. 2):

- Level 1: selection of parts of the glacier surfaces below a slope threshold. Application to regions of $10^{4} \mathrm{~km}^{2}$ to $10^{5} \mathrm{~km}^{2}$ to quickly obtain an overview over large regions.

- Level 2: manual application of three criteria (distinct slope increase, reduction of glacier width, and crevassefree part followed by heavily crevassed part), to detect potential overdeepenings in the glacier bed. Application to regions of $10^{3} \mathrm{~km}^{2}$ to $10^{4} \mathrm{~km}^{2}$ to detect regions and situations of special interest.

- Level 3: use of more detailed tools, which require more input data (e.g. digitized central flow lines) to model the ice thickness distribution (e.g., Farinotti et al., 2009; Linsbauer et al., 2009). The region of application ranges from individual glaciers up to several $10^{4} \mathrm{~km}^{2}$, depending on the model and the availability of required input data.

- Level 4: in-situ geophysical investigations (e.g., radioecho sounding) or drilling in the field for detailed information about the bed topography and bed properties at individual points or transects. Local application for situations that are considered to be critical. This level 4 is not further discussed in this article. 


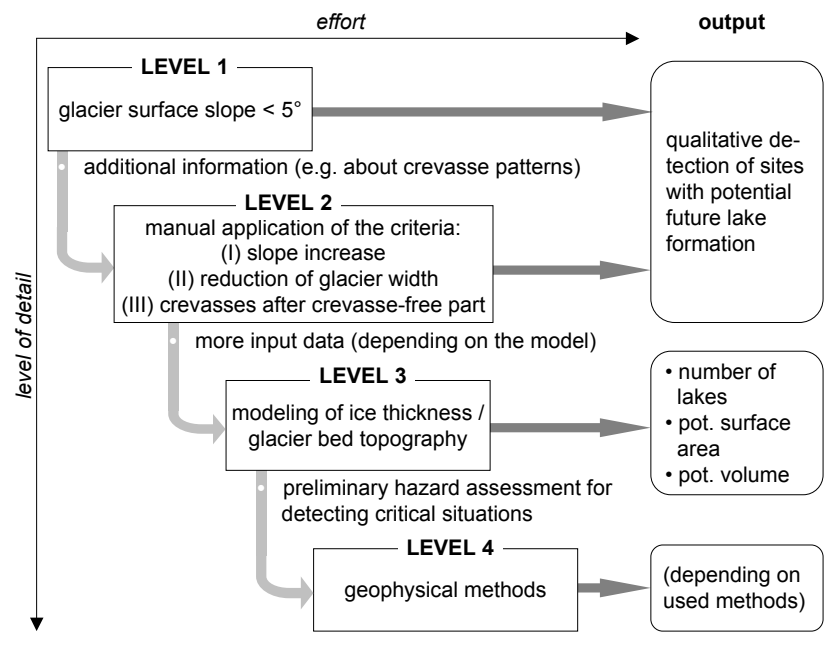

Fig. 2. Illustration of the different levels of the strategy for detecting sites with potential future lake formation.

\subsubsection{Level 1}

Rothenbühler (2006) selected sites with a glacier surface gradient below $5^{\circ}$ and a minimum area of $6250 \mathrm{~m}^{2}$ (ten $25 \mathrm{~m}$ cells) to define sites with potential lake formation on glaciers in the Bernina region. Instead of selecting only parts that consist of 10 connected cells as proposed originally, we here used a median filter that was applied on a 5 by 5 cells moving window (low pass filtering). That way, isolated pixels are eliminated, small holes are filled and the result is smoothed. This threshold algorithm can be easily implemented in a Geographic Information System (GIS) and a first overview of potential overdeepenings can be quickly gained for a large region. The $5^{\circ}$ threshold also includes the critical slope gradient of $2^{\circ}$ for supraglacial lake formation on debris-covered glaciers (Reynolds, 2000).

\subsubsection{Level 2}

Based on simple ice mechanical considerations, we defined three additional criteria for level 2: (I) a distinct break in slope, (II) a reduction in glacier width, and (III) a heavily crevassed glacier part below a crevasse-free part. The explanations for these criteria are as follows:

(I) According to the shallow ice approximation (SIA) and the assumption of perfect plasticity (Paterson, 1994) and thus constant basal shear stress $(\tau)$, the ice thickness $(h)$ only depends on the surface slope $(\alpha)$, averaged over a distance longer than the thickness:

$$
h=\frac{\tau}{F \rho g \sin \alpha}
$$

with $F=$ shape factor, $\rho=$ density of ice, and $g=$ the gravitational acceleration It follows that steep parts of a glacier have thinner ice than flat parts. Thus, depressions in the bed can be expected at places that are above a distinctive break in the surface slope along the flow direction, where a glacier moves from a flat part with thick ice into a steeper section with thinner ice. This is qualitatively correct, although valley glaciers support a considerable amount of the driving stress by lateral drag. The influence of the shape factor $(F)$ (Paterson, 1994), as well as the variability of the basal shear stress $(\tau)$ with different slopes (Haeberli and Schweizer, 1988) are neglected here.

(II) Assuming that cross sections of valley glaciers are uniform, there is an empirical relation between width $(w)$ and ice thickness $(h)$ in the form of

$$
h \sim \frac{w}{c}
$$

with values for the constant $c$ in valley glaciers ranging from 3 for steep slopes to 8 for less pronounced valleys (Benz, 2003; Haeberli and Schweizer, 1988). Accordingly, wide glacier parts have a larger ice thickness than narrow parts and an overdeepening can be expected above a distinct glacier narrowing.

(III) If the glacier has to overcome a negative bed slope at the end of an overdeepened basin, the ice will undergo longitudinal compression and thus has no crevasses (compressive flow), but showing a crevassed surface (extending flow) when overflowing a threshold in the bed (Paterson, 1994). A part without crevasses followed by a heavily crevassed region, mainly with transversal crevasses, can thus indicate an overdeepening. This criterion is often coexistent with criterion (I) and (II), because a distinct increase in slope is often related to a narrowing of the valley and accelerating flow and, thus, a crevassed surface (e.g., Hooke, 1991).

These three criteria are schematically illustrated in Fig. 3. There is no need that all three criteria are fulfilled simultaneously, but often they occur combined. Criteria (I) and (II) can be estimated with terrain information (DEM) whereas for criterion (III) a satellite image of at least $30 \mathrm{~m}$ resolution (e.g. Landsat TM) or better or an aerial photograph can be used. Tools like Google Earth ${ }^{\mathrm{TM}}$ might also be suitable if high-resolution imagery is at hand in those services. If available, also a high resolution DEM - e.g. from airborne LIDAR - can help to identify the crevasse pattern at the surface. In general, large flat glacier parts as used in level 1 are closely related to all the three criteria of level 2 , as often a steeper scarp is following (I), narrow glacier parts normally are steeper than the wide parts (II), and flat parts tend to show no or only few crevasses (III). Therefore, the results of level 1 can be used as a guideline for the manual analysis of level 2. 


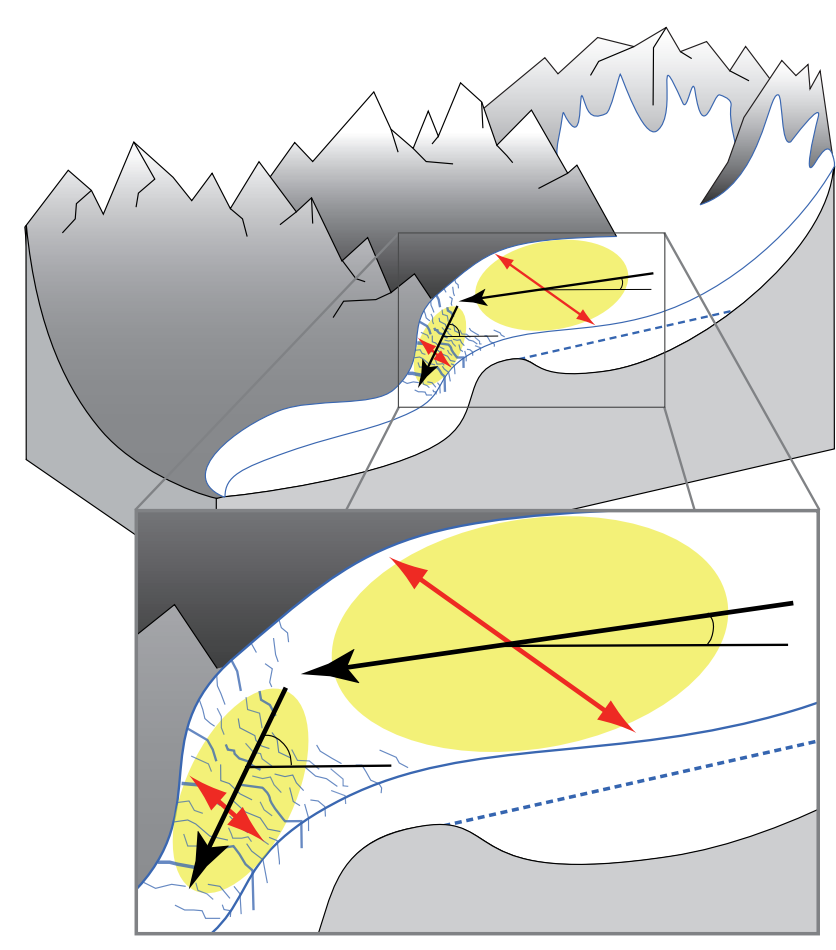

Fig. 3. Simplified schematic sketch of the three criteria that are applied manually on level 2 . The black arrows indicate a distinct break in slope (criterion I), the red arrows show a narrowing of the glacier width (criterion II) and the yellow areas cover a flat and crevassefree region followed by a heavily crevassed area (criterion III). The dashed line in the overdeepening represents the potential future lake level.

\subsubsection{Level 3}

Models like the ones presented by Farinotti et al. (2009) or Linsbauer et al. (2009) estimate the ice thickness distribution or the glacier bed topography, respectively. They proved to be in good agreement with ice thicknesses measured in the field and provide thus helpful tools for the detection of overdeepened parts of the glacier bed. Compared to the results of level 1 and level 2, quantitative information can be gained at this level. Of course, in an absolute sense the modeled glacier beds might have large uncertainties. However, the potential maximum area and volume of a lake as well as topography of the lake bottom and the surrounding terrain after glacier disappearance can be realistically estimated. Compared to the methods for assessments on level 1 and level 2, such models require additional input data (e.g. digitized center lines for major glacier branches and parameters describing the mass balance distribution and the ice flow). Depending on the model, the size of the region that can be processed may be restricted due to limited computational power or the availability of input data. In this study, we used the model of Linsbauer et al. (2009) for comparison and validation purposes, and the modeled glacier bed topography with its overdeepenings was used as input for the modeling of potential future lake outbursts (see Sect. 5). The main workload for this model is given by the manual digitization of flow lines for each glacier and all its main tributaries.

\subsubsection{Level 4}

For more detailed investigations of a specific site, e.g., accurate assessment of potential future lake volume, geophysical measurements like ground penetrating radar (GPR) (e.g., Binder et al., 2009) or even drilling (e.g., Truffer et al., 1999) have to be performed. However, as mentioned before, these methods are not further discussed in this study.

\subsection{Validation}

To validate the methods of the different levels, they were applied to historical data to allow a comparison with the present situation (Fig. 4). For Trift Glacier in the Bernese Alps, where a lake formed after the year 2000, the topographic map (Siegfriedkarte) from 1932 and a photograph from 1948 provide the information for the qualitative assessments. For the quantitative analyses the DHM25L1, representing the surface of 1985, was used.

Analyses on level 1 and 2 based on the historical map are shown in Fig. 4a. The contour lines indicate a surface slope slightly below $5^{\circ}$ (level 1 ) in the region of the present-day lake, and the criteria of level 2 apply as well. In the photograph from 1948 (Fig. 4b), these criteria are illustrated as well, to demonstrate that they can also be applied visually in the field for a rough assessment. Based on the DHM25L1 (dating to 1985) and the digital glacier outlines from 1973 (Paul, 2007), the model from Linsbauer et al. (2009) was used to estimate the glacier bed topography at level 3 (Fig. 4c). The results indicate a distinct depression in the glacier bed with a depth of about $100 \mathrm{~m}$ at the location of the new lake. The surface slope of the glacier in 1985 (calculated from DHM25L1) is slightly larger than in 1932 (measured in the Siegfriedkarte), but the surface gradient near the tongue is still below $5^{\circ}$. Qualitative tests of the strategy on level 1 and level 2 with historical maps were also performed at Rhone Glacier and Gauli Glacier, two other sites with recent lake formation. In both examples, the former glacier surface was flat and all three criteria of level 2 applied as well. Concluding, it can be stated that these lakes could clearly be anticipated from the historic data by the manual application of the three criteria of level 2 and the model used on level 3. The application of the slope threshold on level 1, although being less reliable, also proved to give a quick and sufficiently accurate overview.

\subsection{Modeling potential future lake outbursts}

In order to detect critical situations and cases, which require in-situ investigations on level 4, a hazard assessment concerning the expected lakes is performed based on the results 


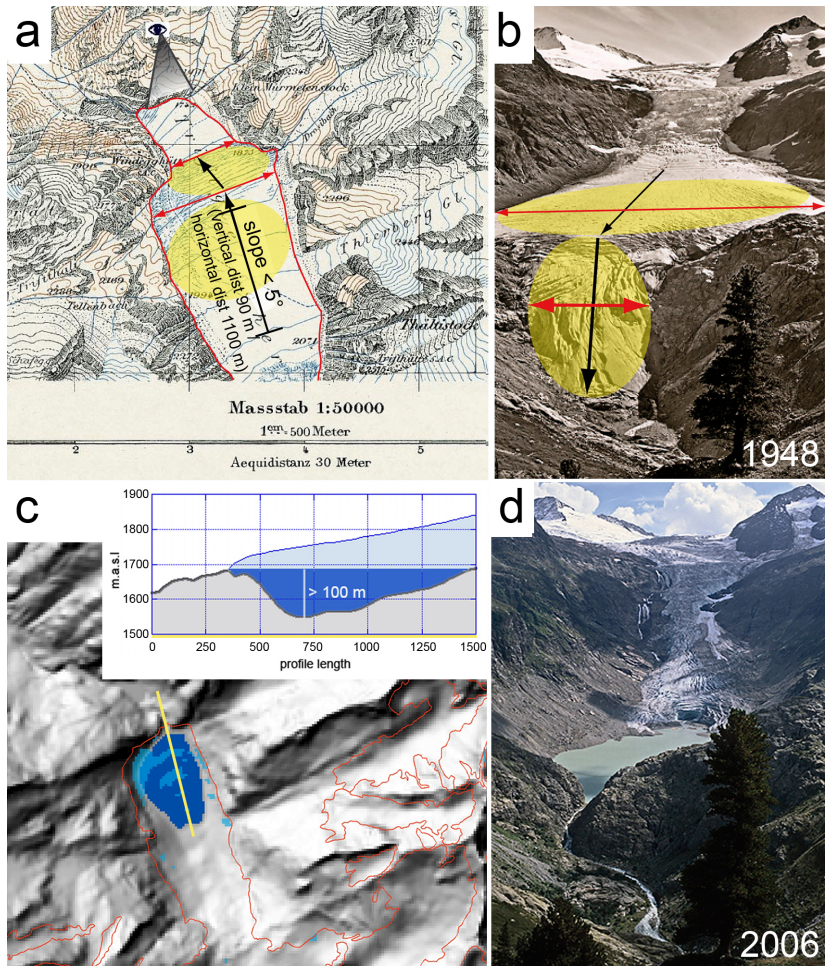

Fig. 4. Application of the strategy to Trift Glacier, using historical data. (a) Level 1 (slope $<5^{\circ}$ ) and level 2 (three criteria, same symbols as in Fig. 2) applied to the Siegfried map from 1932. The eye and the triangle indicate viewing directions of photographs shown in (b) and (d). (b) Photograph from 1948, level 2 criteria are indicated again. (c) Modeled bed topography based on DHM25L1 from 1985 and glacier outlines from 1973 (red lines). The modeled overdeepening (blue) is more than $100 \mathrm{~m}$ deep. Light and transparent blue areas are parts with surface gradient below $5^{\circ}$ (level 1) for comparison. (d) Photograph from 2006, taken from the same location as (b). Photographs (b) and (d) (C) Gesellschaft für ökologische Forschung (www.gletscherarchiv.de).

of level 3. Because these future scenarios have large uncertainties about the exact location, lake volume and properties of the environment surrounding the lakes, such an assessment can only be of preliminary nature. Relationships gained from the analyses of past events showed that for the formation of debris flows, firstly loose sediments must be available for entrainment, and secondly, a minimum channel slope of $8^{\circ}$ is required to mobilize the material (Hungr et al., 1984; O'Connor et al., 2001). So far, the maximum runout distances of coarse debris flows originating from outbursts of ice and moraine dammed lakes in the European Alps have not been documented to fall below $11^{\circ}(\tan \alpha=0.19)$ (Haeberli, 1983; Huggel et al., 2002). This value can thus be used as a limit for worst-case scenarios of debris flow type outburst floods. If no loose sediment is available or slopes are too flat for sediment entrainment and the water volume by far exceeds the sediment volume, flood waves with much longer potential runout distances can form. For such a case, Haeberli (1983) found in an empirical study in the Swiss Alps an overall slope of $2^{\circ}$ to $3^{\circ}$ as maximum distance of the destructive reach of flood waves.

Huggel et al. (2003) presented a simple but robust debris flow model that includes these empirical runout distances and slope thresholds, and that can be applied with reasonable assumptions for the required input data. The so-called modified single flow model (MSF) is a hydrological flow routing model that calculates for each cell of a DEM a probability of affection by a flooding event. It is based on a hydrological algorithm that calculates the flow direction from one DEM cell to another according to the steepest downward gradient between one cell and its eight neighbours. In addition, it allows also a flow spreading of up to $45^{\circ}$ from the main flow direction. The input data are starting cells and a DEM. In this study we used the modeled potential future lake areas as starting zones and the DEM without glaciers obtained on level 3 for flow path modeling. The MSF model can be applied to larger regions, i.e. several lake outbursts can be modeled within one model run. The somewhat speculative and uncertain assumptions about the volume and the sediment concentration of outburst floods are not considered in the model.

\section{Results}

\subsection{Future lake scenarios}

For the Aletsch and for the Bernina test regions, locations with potential future lake formation were delineated based on the results of levels 1 and 2 (Figs. 5 and 6). The DHM25L2 was used for an automated selection of glacier parts with surface slopes below $5^{\circ}$ (level 1, blue areas). For the manual application of the three criteria on level 2, a slope map derived from the DHM25L2, the digital glacier outlines from the SGI, and the IRS-1 C scenes were used.

In Fig. 5 the results for the Aletsch Glacier are shown. Large parts of the glacier surface have a slope gradient below $5^{\circ}$ (blue areas in the figure) and are selected on level 1. This is not surprising, as large glaciers tend to have low mean slope values (Paul, 2007). However, it is unlikely that all these parts with a flat surface are overdeepened. On level 2, the overdeepenings can be located already from the information from level 1, although estimations of the exact positions and sizes of the overdeepenings 2, 3, 5, 9, 10 and 11 are uncertain. On the one hand, it is possible that some of them are connected (e.g. overdeepenings 2 and 3), on the other hand, some of them are likely to be much smaller than indicated. The other overdeepenings were identified according to the following criteria of level 2: at locations 8 and 9, a distinct break in slope (criterion I) applies, at number 1, 6 and 7, a reduction in glacier width further downstream (criterion II), can be observed. Overdeepenings number 4 and 6 are located 


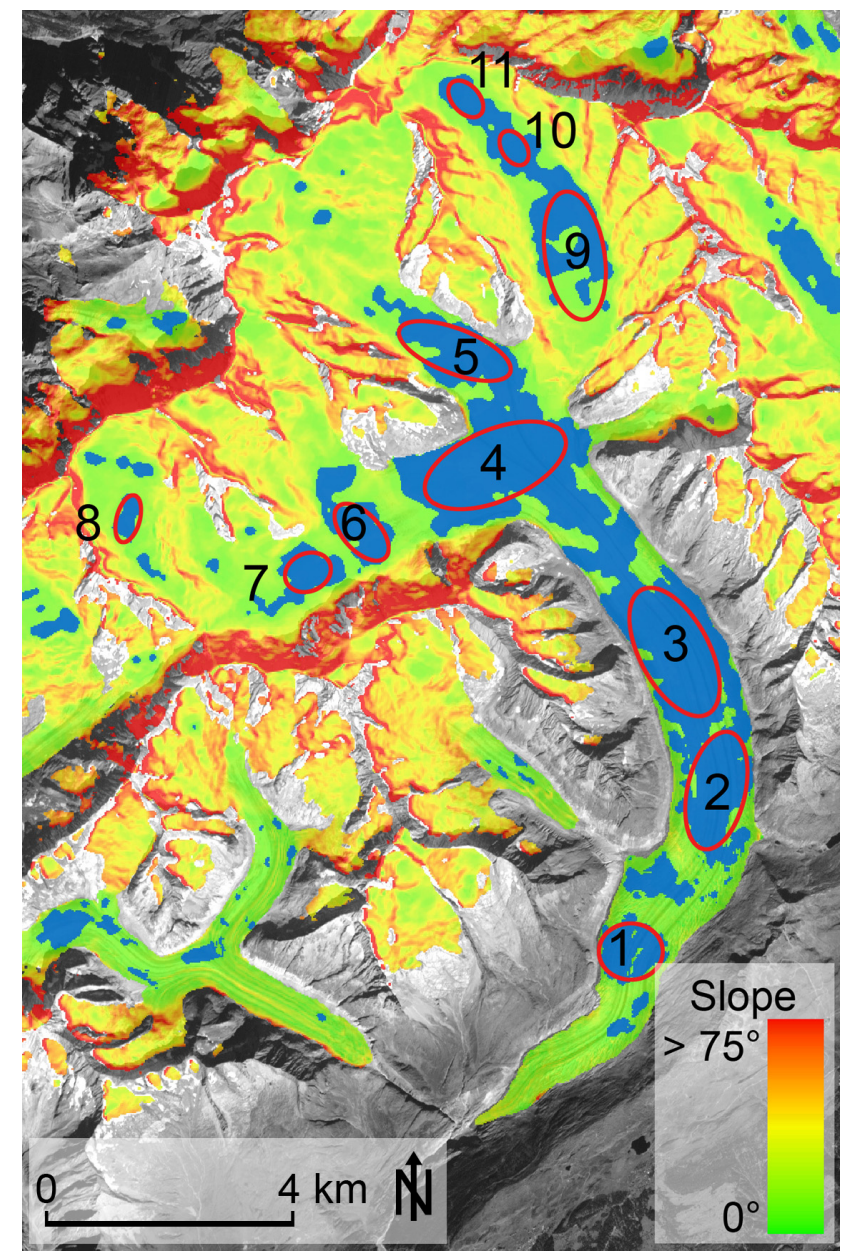

Fig. 5. Potential overdeepenings in the bed of Aletsch Glacier; IRS$1 \mathrm{C}$ scene $(10 \mathrm{~m}$ resolution) in the background. Surface gradient of glaciers is shown in green (flat) to red (steep): results of level 1 are shown in blue (glacier surface parts with slope $<5^{\circ}$ ); and the overdeepenings estimated on level 2 are indicated with red circles. Further explanations are given in the text.

at confluences with tributary glaciers, a factor that favors the erosive power of a glacier (MacGregor et al., 2000).

The application of the methods to the Bernina region is shown in Fig. 6. On level 1, the overdeepenings number 2, 4, 6, 7 and 10 can be identified, while locations 1,3 and 5 are somewhat unclear because only small flat areas are detected. On level 2, numbers 3 and 5 are detected more clearly: all criteria apply at site 3 and criterion (I) and (III) apply for location 5 . Site 7 is considered to be overdeepened as well, because the confluence of the two glacier branches favors erosion. Sites 8 and 9 are identified clearly on this second level, also here all three criteria apply, at site 9 even more clear than at site 8 . However, the surface gradients are slightly steeper than $5^{\circ}$ at both locations.

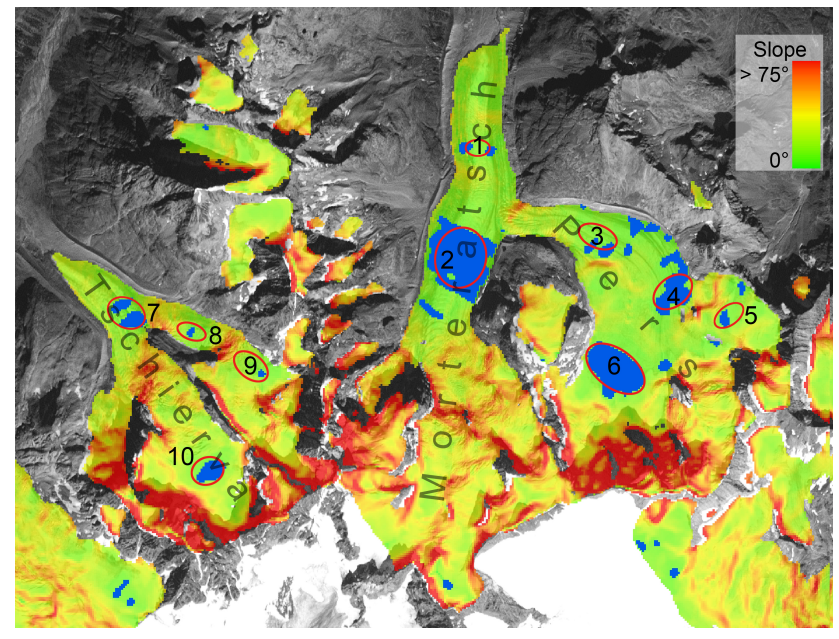

Fig. 6. Potential overdeepenings in the Bernina region; IRS-1C scene $(10 \mathrm{~m}$ resolution) in the background. Surface gradient of glaciers is shown in green (flat) to red (steep): results of level 1 are shown in blue (glacier surface parts with slope $<5^{\circ}$ ); and the overdeepenings estimated on level 2 are indicated with red circles. Further explanations are given in the text.

\subsection{Comparison of qualitative assessment (levels 1 and 2) with modeled overdeepenings (level 3)}

With regard to applications of this strategy to other mountainous regions, we applied only the first two levels on both regions, as it would be the case for remote and unexplored regions, where input data for more detailed investigations are missing. A comparison of the results of these qualitative assessments to the modeled overdeepenings from the estimated bed topography (level 3) is shown in Fig. 7 to reveal the strengths and weaknesses of these first two levels.

According to the interpolated bed topography from level 3 by the model from Linsbauer et al. (2009), there are seven sites in the Bernina region with a potential for the formation of a larger lake in the region of Morteratsch Glacier and Pers Glacier (Fig. $7 \mathrm{~A}$ and 1 to 6). Three of these seven sites, 2, 4 and 6, are detected on level 1 due to their surface slopes below $5^{\circ}$. The modeled overdeepening at site 3 is only weakly indicated on level 1 by the patchy distribution of areas with flat surfaces, but is detected on level 2. At the site 1 , two small patches of flat areas are indicated on level 1, and on level 2 a slight increase in slope (criterion I), however it was still unclear if there is an overdeepening in the bed. At site 5, a small flat part and a distinct increase in slope indicate an overdeepening. The model applied on level 3 shows an overdeepening, however, it is a small depression and it is even possible that the depression is only an artifact of the model and the bed is not overdeepened at all at this location. To assess this in more detail, geophysical measurements must be performed (level 4). Finally, the modeled 


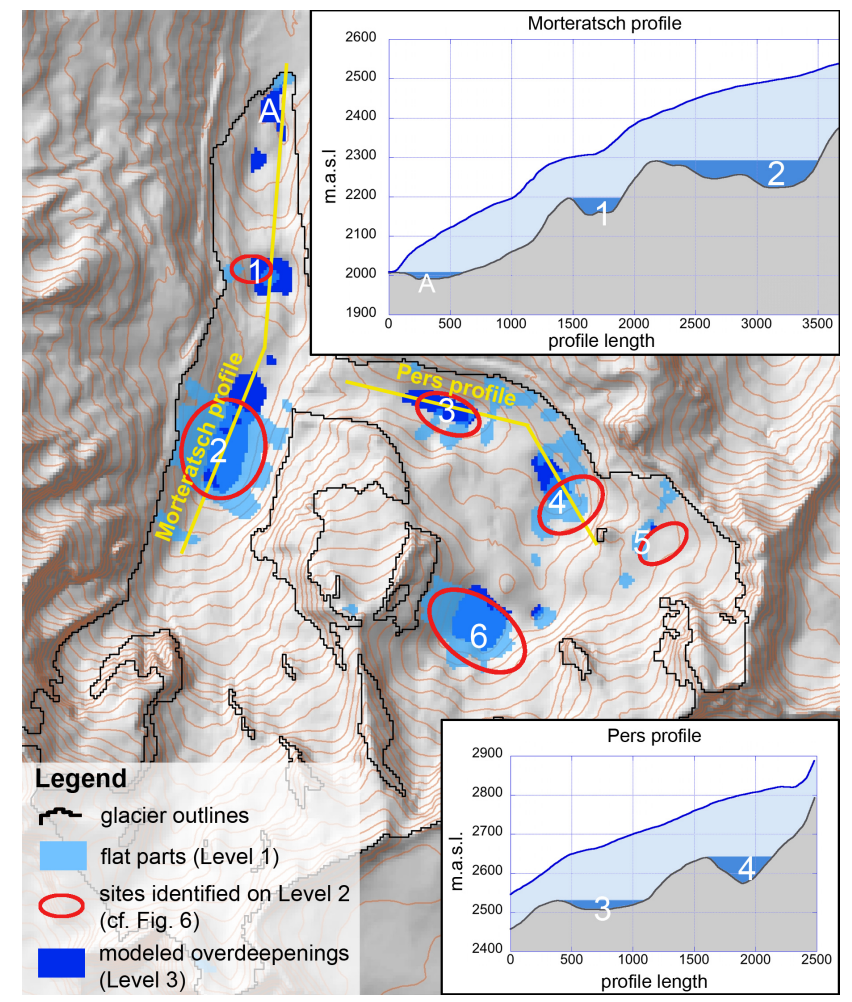

Fig. 7. Comparison of the results from level 1 and 2 with the modeled bed topography (level 3, overdeepenings shown in dark blue, A-G) on Morteratsch- and Pers Glacier (Bernina region), including two profiles. Results from level1 are shown in transparent light blue, results from level 2 are indicated by red circles (compare to Fig. 6).

overdeepening at site A near the terminus may be an artifact of the model due to the interpolation of a concave shaped bed between the last interpolation point and the glacier outline (Linsbauer et al., 2009). Regarding the formation of lakes at these overdeepenings, the temporal component of glacier retreat is important. Generally, lakes form earlier in lower overdeepenings. Transient glacier retreat models could help to estimate the point in time when the formation of a lake will start.

\subsection{Potential for application in other regions}

According to the verification at Trift Glacier and the comparison with the modeled bed topography, the first two levels of the assessment strategy are sufficient for a preliminary and qualitative identification of sites with potential future lake formation in a larger region. In view of applying these methods to other mountain regions of the world, it was tested whether the SRTM DEM and ASTER GDEM can be used within this strategy. Therefore, for both DEMs the Morteratsch region was clipped, reprojected to the Swiss coordinate system, horizontally adjusted to the DHM25L2 (Paul and Haeberli, 2008) and resampled to $25 \mathrm{~m}$ by bilinear inter-

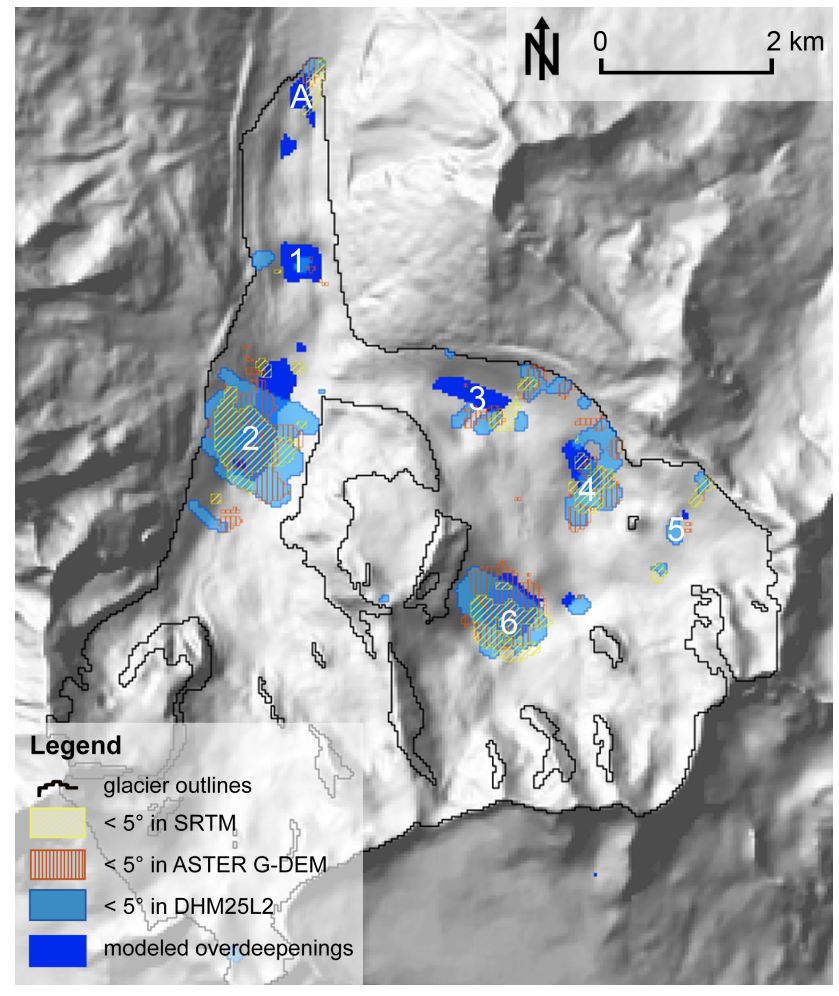

Fig. 8. Glacier surface areas with slope $<5^{\circ}$ (level 1) on Morteratsch- and Pers Glacier derived from the ASTER GDEM (yellow) and SRTM (orange). For comparison, flat parts derived from the DHM25L2 (light blue) and overdeepenings in the modeled glacier bed (blue) are shown as well. The background is a hillshade view of the modeled bed topography and the DHM25L2 outside the glacier margins.

polation. In contrast to the processing of the DHM25L2 on level 1 (see Sect. 3.1.1), no filter was applied to the flat regions derived from the SRTM and the ASTER GDEM. They were smoothed already during the resampling process. The selection of flat glacier parts with surface slopes below $5^{\circ}$ (level 1) is shown in Fig. 8. Flat parts from the high-quality DHM25L2 and the overdeepenings in the modeled bed topography are also shown. The larger overdeepenings at sites 2, 4 and 6 can be identified in both other DEMs clearly; 3 and 5 remain unclear on level 1. Flat parts derived from both DEMs are smaller compared to the DHM25L2 and small flat parts in the latter are not represented in the other DEMs. This is due to the coarser resolution of the original datasets. In general, the results from SRTM correspond slightly better to the results from the DHM25L2 than the results derived from the ASTER GDEM.

For the second level, slope masks (not shown here) were derived from the two additional DEMs. Again, compared to the DHM25L2 both slope masks are less detailed and show more artifacts. Also, the larger overdeepenings can be identified again; but smaller ones remain unclear or cannot be 
resolved. However, because the information extracted from the DEMs is only used for a qualitative assessment on level 1 and 2, they are both considered to be suitable for being used within this strategy, at least on the first two levels. Assuming that the quality of these datasets is similar in other mountain regions, these DEMs allow an application of the presented strategy also beyond the European Alps.

\section{Assessing potential future glacier lake outburst}

In this study, the temporal evolution of glacier retreat and thus also the temporal evolution of lake formation is not considered. Instead, runout paths for worst-case scenarios of glacier lake outburst are modeled: all glaciers have retreated strongly, most parts of the beds are exposed, and all overdeepenings modeled on level 3 are completely filled with water. Based on this setup, potential future lake outbursts are modeled for the Morteratsch- and Pers Glaciers, also to demonstrate the potential of simple flow-routing models like the MSF model (Huggel et al., 2003) that can be used in such cases with highly uncertain conditions. Based on the results of such a preliminary assessment, sites that require more detailed investigations on level 4 can be selected. Nevertheless, the temporal evolution of glacier retreat and lake formation has a direct influence on the hazard situation. For example, after the formation of a lake at overdeepening 3 in Fig. 7, Pers Glacier will terminate in a steeper part of the bed and thus favor the formation of ice avalanches. The new lake in front of this tongue might be in the runout distance of such ice avalanches. After continued retreat of Pers Glacier, the situation might become less critical.

\subsection{Potential future lake outbursts at Morteratsch Glacier and Pers Glacier}

The results of the MSF modeling are shown in Fig. 9. According to the modeled bed topography, the lakes are all hydrologically connected, in other words, many of the outburst floods reach other lakes located further downstream. This is inherent to the applied model approach, because the largest depths are modeled along the central flow line. However, this is also realistic from a glaciological point of view, because the depressions were shaped by the same glacier. The slope values from the modeled glacier bed exceed $8^{\circ}$ in the surrounding of most future lakes, hence, loose material could be entrained by outburst floods from these lakes. The average slope values of the glacier beds are around $25^{\circ}$, but below the glacier tongues the terrain levels out. Even in worst-case scenarios with runout distances for debris flows according to an $11^{\circ}$ average slope threshold (Haeberli, 1983; Huggel et al., 2002), debris flows from future glacier lakes could reach lakes situated below, but in most cases the affected areas are confined to regions close to the lakes; they do not reach presently existing buildings, settlements or other expensive infrastructure (Fig. 9a).

Because it is highly uncertain how much loose sediment will be available in the future, we also modeled potential flood waves, which, compared to debris flows, have a much lower sediment concentration (Fig. 9b). For the maximum runout distance we chose again a worst-case approach and used a maximum average slope of $3^{\circ}$ (see Sect. 3.3).

In the combined modeling of the whole region in a single model run, the MSF model calculates the average slope always from the lowest starting zone. In other words, if a lake outburst flood reaches a lower lake, the modeling of the flood from the upper lake is aborted and only the flow path from the lower lake is calculated. This is reasonable because a debris flow or flood wave from an upstream lake can trigger an outburst of a lower lake, but the kinetic energy of the incoming flow mass will be used to displace the water from the lower lake. However, in the case of modeling outbursts from potential future lakes, it is uncertain which lakes will form at all and when. It is possible that a lower lake is filled with sediments, drained already earlier, or did never form at all. For this reason, we modeled flood waves for all potential future lakes individually to avoid undesirable interactions.

The maximum runout paths of the individual flood waves are shown in Fig. 9c. According to the model, the floods could reach existing settlements and infrastructure. Flood waves from all these potential future lakes could affect the roads and the railroad in the Bernina Valley. Floods originating from the bed of Morteratsch Glacier would not reach Pontresina (P), but all expected future lakes of Pers Glacier have the potential to cause flood waves that could reach the village of Samedan (S).

The influence of lakes located in the runout of an upstream lake can be shown with the example of the lowest lake on Morteratsch Glacier (M1). If this depression is empty of water during an outburst of $\mathrm{P} 1, \mathrm{P} 2$ or $\mathrm{P} 3$, the potential destructive reach of such a flood wave could reach the flood plain of Samedan, where a regional airport is located. But if there is a full lake at M1, it could absorb the energy from an outburst of a smaller lake upstream. Of course this depends strongly on the volume and geometry of the retention basin at M1 and the magnitude of the outburst flood from P1, P2 and P3. From these finding the hypothesis arises, that a lake of a sufficient size, located at the transition from steep terrain to a flat valley bottom reduces the hazard potential of other lakes located higher up in steep terrain. This is only the case, if the lower lake is large enough and has a sufficiently stable dam to absorb the kinetic energy of an incoming flood wave from an upstream lake outburst. 

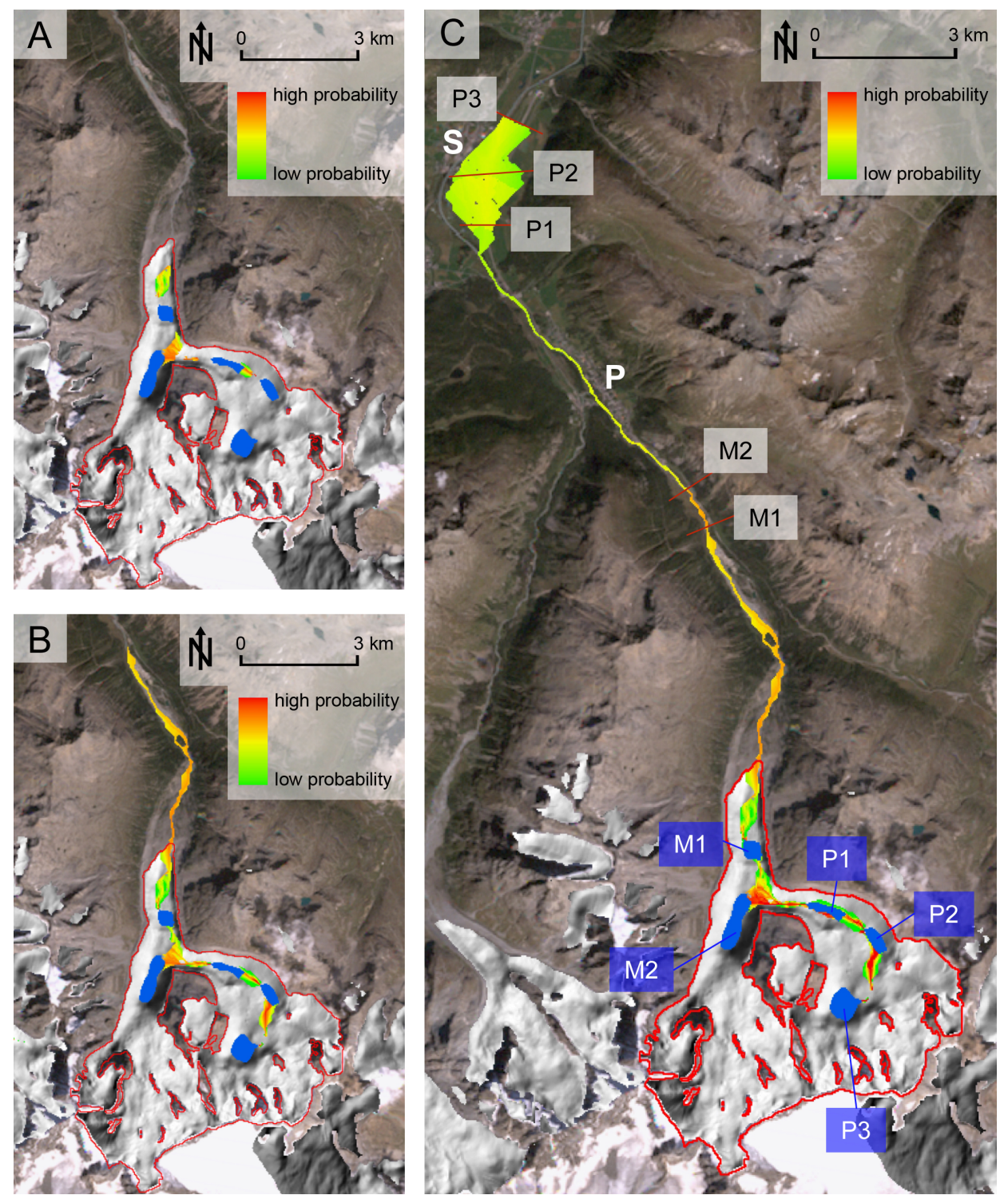

Fig. 9. Flow routes of outbursts from potential future glacier lakes of Morteratsch (M1, M2) and Pers Glacier (P1-P3) modeled with the MSF algorithm. Background image is a Landsat 5 TM scene from 1999; glaciers were replaced by hillshade views of the modeled glacier beds. (A) debris flows; (B) flood waves modeled in one model run (runout path is interrupted as soon as another lake is reached); (C) flood wave paths modeled for each glacier individually. The starting points are indicated by blue boxes; respective maximum destructive runout distances are shown in grey boxes. Indicated settlements are Pontresina (P) and Samedan (S).

\section{Discussion and perspectives}

The presented strategy to detect sites with potential future lake formation on four different levels proved to be feasible and the results of the different levels are consistent. In the Bernina region all the overdeepenings in the modeled bed topography at level 3 could be identified on the previous levels already. Regarding an application to other mountain regions of the world, where only sparse input data may be available, the methods of these first two levels can quickly provide qualitative information without much computational effort.
For such an approach, designed to anticipate future scenarios, it is essential that all overdeepenings are identified, even though not all of them may cause lake formation. In statistical terminology type II errors (false negatives; in this case a real overdeepening that is not detected by the strategy) must be minimized. It is therefore accepted that too large areas are selected at level 1. But because the real glacier bed topography and its properties are not known before glacier disappearance, the value of this type II error cannot be quantified precisely. 
So far, glacier sedimentation was not considered in this study. The sedimentary properties of the glacier beds that will be uncovered in the future have a twofold impact on potential lake formation: on the one hand, continued sedimentation can fill overdeepenings in the bedrock and thus reduce the lake volume or prevent lake formation at all. On the other hand, sedimentary glacier beds can provide loose material for debris flow formation and lead to moraine dammed lakes with a potential for mechanical dam failures and related extreme discharges. Maisch et al. (1999) presented an index to discriminate sedimentary and rocky glacier beds, based on the heights of surroundig rock walls and a number of glacier characterisitcs. Zemp et al. (2005) implemented this index into a GIS, which allows including it in the suggested assessment strategy at level 3, e.g. supplementary to the modeling of potential outburst floods.

The methods of this study were developed and tested for glaciers without extensive debris cover. However, supraglacial lakes can also develop on debris-covered glaciers of the Alps, e.g. on the Belvedere Glacier in Italy or on the tongue of the Lower Grindelwald Glacier in Switzerland. Reynolds (2000) anticipated sites with potential supraglacial lake formation on heavily debris-covered glaciers in the Himalayas (Bhutan) by identifying stagnant parts of the glacier tongue with average surface slopes below $2^{\circ}$. This approach was later confirmed by a study of Quincey et al. (2007) who investigated the flow velocities of debris-covered tongues in Nepal and Tibet (China) by using synthetic aperture radar (SAR)-interferometry. In principle, this procedure corresponds to our approach at level 1 and level 2, respectively. The different lake formation processes explain the differences of the slope values for level 1: on debris-covered tongues, lake formation normally starts with the occurrence of small individual supraglacial ponds that coalesce later to a single lake, which finally grows constantly by melting the adjacent ice in all directions (mainly upstream). This process can take the whole valley width and finally even replace a large part of the tongue (Bolch et al., 2008; Komori, 2008; Reynolds, 2000; Watanabe et al., 1994). Our approach is related to proglacial lake formation at (nearly) debris-free glaciers where lake formation starts at the (retreating) glacier front. Thus, the threshold slope value for the detection of glacier-bed overdeepenings is greater than for supraglacial lake formation on debris-covered tongues $\left(5^{\circ}\right.$ instead of $\left.2^{\circ}\right)$.

The formation of a lake that is in contact with a glacier can have a strong impact on glacier dynamics. In general, a lake at the front of a glacier will accelerate glacier retreat due to increased ablation by calving and thermokarst effects (Kääb and Haeberli, 2001). For this reason, length changes of glaciers that terminate into a lake, are to a certain degree decoupled from the direct forcing of climate change and should thus not be used as indicators of climatic changes. Chinn et al. (2008) estimated an increase in the rate of ice loss by about one order of magnitude for glaciers terminating in a lake compared to other glaciers with ice loss only due to surface melt. These authors also state, that the inclined glacier surfaces are replaced by horizontal water surfaces which results in steeper upslope glacier surfaces and, hence, in faster ice flow. Such impacts of glacier lake formation on glacier dynamics are not commonly taken into account for physically based, dynamic modeling of future glacier development (e.g., like in the studies from Jouvet et al., 2009 or Le Meur et al., 2007). In combination with such models of transient glacier evolution, the temporal component could be included in the assessment of future lake formation. So far, only relative predictions of sequence of lake formation for individual glacier branches are possible by locating the bed-overdeepenings (first, the lake at the lowest overdeepening will form). As soon as multi-tributary glaciers start to separate into individual glaciers, the order of formation may change. For example, Morteratsch and Pers Glacier will separate in the near future and it is possible, that a lake at overdeepening 3 (Fig. 7) will form earlier than the lower lake at overdeepening 2 due to different retreat rates caused by different ice thicknesses of the individual glacier branches.

In this study outburst floods were modeled, but other important components for the determination of the hazard potential of future lakes were not considered. Dam characteristics for example strongly influence the risk of failure, and external factors like impact waves from mass movements can trigger catastrophic lake outbursts. To allow a more detailed and integrated hazard assessment of lakes expected to form in the future, such components must be anticipated as well. More detailed assumptions about the lake size, dam properties and lake surrounding would allow a more sophisticated modeling of potential lake outbursts.

\section{Conclusions}

The presented integrated four-level strategy for the detection of sites with potential glacier lake formation is a suitable approach to anticipate future situations in high-mountain environments. Starting with the first level to gain a rough overview over a large region, the strategy subsequently focuses on smaller regions in more detail, down to in-situ geophysical measurements in the field. This multiscale procedure allows to rapidly identifying the most critical sites in a large region. Applications of the strategy to two test regions showed, that the newly presented, qualitative approaches (levels 1 and 2) proved to be consistent with the results from more detailed/laborious models that are applied on the third level. In both test regions, ten or more overdeepenings were detected and the formation of several glacier lakes has to be expected in the future. Due to the irregular longitudinal bed profiles caused by glacier erosion (Hooke, 1991), glacier lakes will form in the course of continued glacier retreat in cold mountain regions. Tests of the presented strategy with the nearly globally available SRTM and ASTER DEMs revealed satisfying results. This indicates that the approach 
can be applied worldwide, even in remote regions with less detailed data coverage.

The hazard situation of such glacier lakes needs to be (re-)assessed regularly and at short time intervals, because these lakes form in a rapidly changing environment and their hazard potential is determined by factors that are themselves subject to changes. Modeling of potential glacier lake outbursts is an important part of such a hazard assessment and can also be performed for glacier lakes that are expected to form in the future. The modeling of potential debris flows and flood waves originating from anticipated future lakes of the Morteratsch- and Pers glaciers indicated that a growing number of lakes may not in all cases imply a higher regional hazard potential.

To predict the time of lake formation, the here-presented strategy needs to be coupled with simple but transient models that determine glacier retreat over large regions. Such a combination is in the focus of future research and will further increase the benefit of the presented approaches.

Acknowledgements. We are grateful to J. Bordonau and an anonymous reviewer whose comments helped to improve the quality of this paper. In Figs. 4c, 5, 6, 7, 8 and 9 the DHM25 is reproduced by permission of swisstopo (BA100064). Funding of this study was partly provided by the ESA project GlobGlacier (21088/07/I-EC).

Edited by: J. M. Vilaplana

Reviewed by: J. Bordonau and another anonymous referee

\section{References}

Alean, J.: Ice avalanches: some empirical information about their formation and reach, J. Glaciol., 31, 324-333, 1985.

Allen, S. K., Schneider, D., and Owens, I. F.: First approaches towards modelling glacial hazards in the Mount Cook region of New Zealand's Southern Alps, Nat. Hazards Earth Syst. Sci., 9, 481-499, 2009,

http://www.nat-hazards-earth-syst-sci.net/9/481/2009/.

Augustinus, P.: Glacial valley cross-profile development: the influence of in situ rock stress and rock mass strength, with examples from the Southern Alps, New Zealand, Geomorphology, 14, 8797, 1995.

Ballantyne, C.: Paraglacial geomorphology, Quaternary Sci. Rev., 21, 1935-2017, 2002.

Benz, C.: Der würmeiszeitliche Rheingletscher-Maximalstand: Digitale Rekonstruktion, Modellierung und Analyse mit einem Geographischen Informationssystem, Ph.D. thesis, University of Zurich, 2003.

Binder, D., Brückl, E., Roch, K., Behm, M., Schöner, W., and Hynek, B.: Determination of total ice volume and ice-thickness distribution of two glaciers in the Hohe Tauern region, Eastern Alps, from GPR data, Ann. Glaciol., 50, 71-79, 2009.

Bolch, T., Buchroithner, M. F., Peters, J., Baessler, M., and Bajracharya, S.: Identification of glacier motion and potentially dangerous glacial lakes in the Mt. Everest region/Nepal using spaceborne imagery, Nat. Hazards Earth Syst. Sci., 8, 13291340, 2008,

http://www.nat-hazards-earth-syst-sci.net/8/1329/2008/.
Chinn, T., Salinger, J., Fitzharris, B., and Willsman, A.: Glaciers and climate, Bulletin of the Federated Mountain Clubs of NZ, 171, 1-15, 2008.

Clague, J. and Evans, S.: Formation and failure of natural dams in the Canadian Cordillera, Geological Survey of Canada Bulletin, 464, 35 pp., 1994.

Clague, J. and Evans, S.: A review of catastrophic drainage of moraine-dammed lakes in British Columbia, Quarternary Sci. Rev., 19, 1763-1783, 2000.

Costa, J. and Schuster, R.: The formation and failure of natural dams, Geol. Soc. Am. Bull., 7, 1054-1068, 1988.

Evans, S. and Clague, J.: Recent climatic change and catastrophic geomorphic processes in moutnain environments, Geomorphology, 10, 107-128, 1994.

Farinotti, D., Huss, M., Bauder, A., Funk, M., and Truffer, M.: A method to estimate the ice volume and ice-thickness distribution of alpine glaciers, J. Glaciol., 55, 1-9, 2009.

Farr, T. G., Rosen, P. A., Caro, E., Crippen, R., Duren, R., Hensley, S., Kobrick, M., Paller, M., Rodriguez, E., Roth, L., Seal, D., Shaffer, S., Shimada, J., Umland, J., Werner, M., Oskin, M., Burbank, D., and Alsdorf, D.: The Shuttle Radar Topography Mission, Rev. Geophys., 45, 1-33, 2007.

Fischer, L., Kääb, A., Huggel, C., and Noetzli, J.: Geology, glacier retreat and permafrost degradation as controlling factors of slope instabilities in a high-mountain rock wall: the Monte Rosa east face, Nat. Hazards Earth Syst. Sci., 6, 761-772, 2006, http://www.nat-hazards-earth-syst-sci.net/6/761/2006/.

Frey, H., Huggel, C., Paul, F., and Haeberli, W.: Automated detection of glacier lakes based on remote sensing in view of assessing associated hazard potentials, in: Proceedings of the 10th International Symposium on High Mountain Remote Sensing Cartography. Grazer Schriften der Geographie und Raumforschung, edited by: Kaufmann, V. and Sulzer, W., vol. 45, in press, 2010.

GCOS: Implementation plan for the Global Observing System for Climate in support of the UNFCCC, GCOS - 92, WMO, Geneva, 2004.

Gruber, S. and Haeberli, W.: Permafrost in steep bedrock slopes and its temperature-related destabilization following climate change, J. Geophys. Res., 112, F02S18, doi:10.1029/2006JF000547, 2007.

Haeberli, W.: Frequency and characteristics of glacier floods in the Swiss Alps, Ann. Glaciol., 4, 85-90, 1983.

Haeberli, W.: Changing views on changing glaciers, in: The Darkening Peaks: Glacial Retreat in Scientific and Social Context, edited by: Orlove, B., Wiegandt, E., and Luckman, B., Berkeley: University of California Press, 2005.

Haeberli, W. and Beniston, M.: Climate change and its impacts on glaciers and permafrost in the Alps, Ambio, 27, 258-265, 1998.

Haeberli, W. and Hohmann, R.: Climate, Glaciers and Permafrost in the Swiss Alps 2050: Scenarios, Consequences and Recommendations, Proceedings of the 9th International Conference on Permafrost 2008, Fairbanks, Alaska, USA, 2008.

Haeberli, W. and Schweizer, J.: Rhonegletscher 1850: Eismechanische Überlegungen zu einem historischen Gletscherstand, Mitteilungen VAW/ETHZ, 94, 59-70, 1988.

Haeberli, W., Rickenmann, D., Zimmermann, M., and Rösli, U.: Murgänge, in: Ursachenanalyse der Hochwasser 1987, Ergebisse der Untersuchungen, vol. 4, Mitteilungen des Bundesamtes für Wasserwirtschaft, 77-88, 1991. 
Haeberli, W., Kääb, A., Mühll, D. V., and Teysseire, P.: Prevention of outburst floods from periglacial lakes at Grubengletscher, Valais, Swiss Alps, J. Glaciol., 47, 111-122, 2001.

Hayakawa, Y. S., Oguchi, T., and Lin, Z.: Comparison of new and existing global digital elevation models: ASTER G-DEM and SRTM-3, Geophys. Res. Lett., 35, L17404, doi:10.1029/ 2008GL035036, 2008.

Hooke, R.: Positive feedbacks associated with erosion of glacial cirques and overdeepenings, Geol. Soc. Am. Bull., 103, 11041108, 1991.

Hubbard, B., Heald, A., Reynolds, J., Quincey, D., Richardson, S., Luyo, M., Portilla, N., and Hambrey, M.: Impact of a rock avalanche on a moraine-dammed proglacial lake: Laguna Safuna Alta, Cordillera Blanca, Peru, Earth Surface Processes and Landforms, 30, 1251-1264, 2005.

Huggel, C.: Recent extreme slope failures in glacial environments: effects of thermal perturbation, Quaternary Sci. Rev., 28, 11191130, doi:10.1016/j.quascirev.2008.06.007, 2009.

Huggel, C., Kääb, A., Haeberli, W., Teysseire, P., and Paul, F.: Remote sensing based assessment of hazards from glacier lake outbursts: a case study in the Swiss Alps, Can. Geotech. J., 39, 316-330, 2002.

Huggel, C., Kääb, A., Haeberli, W., and Krummenacher, B.: Regional-scale GIS-models for assessment of hazards from glacier lake outbursts: evaluation and application in the Swiss Alps, Nat. Hazards Earth Syst. Sci., 3, 647-662, 2003, http://www.nat-hazards-earth-syst-sci.net/3/647/2003/.

Huggel, C., Haeberli, W., Kääb, A., Bieri, D., and Richardson, F.: An assessment procedure for glacial hazards in the Swiss Alps, Can. Geotech. J., 41, 1068-1083, 2004.

Hungr, O., Morgan, G. C., and Kellerhals, P.: Quantitative analysis of debris hazards for design of remedial measures, Can. Geotech. J., 21, 663-677, 1984.

Jouvet, G., Huss, M., Blatter, H., Picasso, M., and Rappaz, J.: Numerical simulation of Rhonegletscher from 1874 to 2100 , J. Comput. Phys., 228, 6426-6439, 2009.

Kääb, A. and Haeberli, W.: Evolution of a high-mountain thermokarst lake in the Swiss Alps, Arctic, Antarctic, and Alpine Research, 33, 385-390, 2001.

Kääb, A., Huggel, C., Fischer, L., Guex, S., Paul, F., Roer, I., Salzmann, N., Schlaefli, S., Schmutz, K., Schneider, D., Strozzi, T., and Weidmann, Y.: Remote sensing of glacier- and permafrostrelated hazards in high mountains: an overview, Nat. Hazards Earth Syst. Sci., 5, 527-554, 2005,

http://www.nat-hazards-earth-syst-sci.net/5/527/2005/.

Kershaw, J., Clague, J., and Evans, S.: Geomorphic and sedimentological signature of a two-phase outburst flood from morainedammed Queen Bess Lake, British Columbia, Canada, Earth Surface Processes and Landforms, 30, 1-25, 2005.

Komori, J.: Recent expansions of glacial lakes in the Bhutan Himalayas, Quaternary International, 184, 177-186, 2008.

Le Meur, E., Gerbaux, M., Schäfer, M., and Vincent, C.: Disappearance of an Alpine glacier over the 21st Century simulated from modeling its future surface mass balance, Earth Planet. Sci. Lett., 261, 367-374, 2007.

Lemke, P., Ren, J., Alley, R., Allison, I., Carrasco, J., Flato, G., Fujii, Y., Kaser, G., Mote, P., Thomas, R., and Zhang, T.: Observations: Changes in Snow, Ice and Frozen Ground, in: Climate Change 2007: The Physical Science Basis. Contribution of
Working Group I to the Fourth Assessment Report of the Intergovernmental Panel on Climate Change, edited by: Solomon, S., Qin, D., Manning, M., Chen, Z., Marquis, M., Averyt, K., Tignor, M., and Miller, H., Cambridge University Press, Cambridge, United Kingdom and New York, NY, USA 2007.

Linsbauer, A., Paul, F., Hoelzle, M., Frey, H., and Haeberli, W.: The Swiss Alps Without Glaciers - A GIS-based Modelling Approach for Reconstruction of Glacier Beds, in: Geomorphometry 2009 Conference Proceedings, edited by: Purves, R., Gruber, S., Straumann, R., and Hengl, T., University of Zurich, Zurich, 243247, www.geomorphometry.org, 2009.

MacGregor, K., Anderson, R., Anderson, S., and Waddington, E.: Numerical simulations of glacial-valley longitudinal profile evolution, Geology, 28, 1031-1034, 2000.

Maisch, M., Haeberli, W., Hoelzle, M., and Wenzel, J.: Occurrence of rocky and sedimentary glacier beds in the Swiss Alps as estimated from glacier-inventory data, Ann. Glaciol., 28, 231-235, 1999.

O'Connor, J. E., Hardison, J. H., and Costa, J. E.: Debris flows from failures of neoglacial-age moraine dams in the Three Sisters and Mount Jefferson wilderness areas, Oregon, USGS professional paper, 1606, 2001.

Oerlemanns, J.: Glaciers and Climate Change, A.A. Balkema Publishers, ISBN 9026518137, 2001.

Oppikofer, T., Jaboyedoff, M., and Keusen, H.-R.: Collapse at the eastern Eiger flank in the Swiss Alps, Nature Geosci., 1, 531535, 2008.

Paterson, W.: The physics of glaciers, Pergamon Press, Oxford, 3rd edn., 1994.

Paul, F.: The New Swiss Glacier Inventory 2000 - Application of Remote Sensing and GIS. Schriftenreihe Physische Geographie, 52, Ph.D. thesis, University of Zurich, 2007.

Paul, F. and Haeberli, W.: Spatial variability of glacier elevation changes in the Swiss Alps obtained from two digital elevation models, Geophys. Res. Lett., 35, L21502, doi:10.1029/2008GL034718, 2008.

Quincey, D., Richardson, S., Luckman, A., Lucas, R., Reynolds, J., Hambrey, M., and Glasser, N.: Early recognition of glacial lake hazards in the Himalaya using remote sensing datasets, Global Planet. Change, 56, 137-152, 2007.

Raup, B., Racoviteanu, A., Khalsa, S., Helm, C., Armstrong, R., and Arnaud, Y.: The GLIMS geospatial glacier database: A new tool for studying glacier change, Global Planet. Change, 56, 101110, 2007.

Reynolds, J. M.: On the formation of supraglacial lakes on debriscovered glaciers, in: Debris-Covered Glaciers. Proceedings of a workshop held at Seattle, Washington, USA, September 2000, edited by: Nakawo, M., Raymond, C., and Fountain, A., 153161, IAHS Publication, 2000.

Reynolds Geo-Science Ltd: Guidelines for the management of glacial hazards and risks, Reynolds Geo-Science Ltd, Mold, UK, 2003.

Richardson, S. and Reynolds, J.: An overview of glacial hazards in the Himalayas, Quaternary Int., 65-66, 31-47, 2000a.

Richardson, S. D. and Reynolds, J. M.: Degradation of ice-cored moraine dams: implications for hazard development, in: DebrisCovered Glaciers, edited by: Nakawo, M., Raymond, C. F., and Fountain, A., Proceedings of a workshop held at Seattle, Washington, USA, September 2000, Oxford, IAHS Publication, 
2000b.

Rothenbühler, C.: GISALP: Räumlich-zeitliche Modellierung der klimasensitiven Hochgebirgslandschaft des Oberengadins, Ph.D. thesis, University of Zurich, 2006.

Swisstopo: DHM25 - The digital height model of Switzerland. Product information, http://www.swisstopo.admin.ch/internet/ swisstopo/en/home/products/height/dhm25.html, 2004.

Truffer, M., Motyka, R., Harrison, W., Echelmeyer, K., Fisk, B., and Tulaczyk, S.: Subglacial drilling at Black Rapids Glacier, Alaska, USA: drilling method and sample descriptions, J. Glaciol., 45, 495-505, 1999.
Watanabe, T., Ives, J., and Hammond, J.: Rapid growth of a glacial lake in Khumbu Himal, Himalaya: Prospects for a catastrophic flood, Mountain Research and Development, 14, 329-340, 1994.

WGMS: Global Glacier Changes: facts and figures, edited by: Zemp, M., Roer, I., Kääb, A., Hoelzle, M., Paul, F., and Haeberli, W., UNEP, World Glacier Monitoring Service, Zurich, Switzerland, 2008.

Zemp, M., Kääb, A., Hoelzle, M., and Haeberli, W.: GIS-Based modelling of glacial sediment balance, Zeitschrift für Geomorphologie N.F., 138, 113-129, 2005. 